\title{
Helping ESL Students Cope With Content-Based Texts
}

Margaret Early

Gloria M. Tang

The purpose of this article is to propose the use of key visuals as a technique to prepare students to read content text. Based on a specific Language and Content conceptual framework (Mohan 1986), the use of key visuals as a pre-reading strategy acknowledges the role of schema theory in the reading process. This paper describes the strategy; discusses procedures for the construction and implementation of key visuals in content classrooms with examples from the Vancouver School Board Language and Content Project; and, reports briefly the results of an evaluation study which provide tangible evidence of the facilitative effect of key visuals on reading comprehension.

The idea of teaching English through content instruction (Chamot 1983; Chamot \& O'Malley 1986; Early, Thew \& Wakefield 1986; Early, Mohan \& Hooper 1989; Mohan 1986; Wong-Fillmore 1989; Brinton, Snow \& Wesche 1989) is not new. English as a Second Language (ESL) teachers recognize the need to make the regular curriculum and subject matter texts more accessible to ESL learners: they are aware that teaching grammar structures and vocabulary in isolation does not begin to prepare their students for the demands of cognitive academic language in subject disciplines. Likewise, content teachers are seeking instructional strategies that will help their ESL students to acquire subject matter knowledge appropriate to their intellectual level before these learners have acquired the academic linguistic proficiency expected of their native-English-speaking peers. However, the integration of language development for ESL students into subject-area curriculum is not easy to accomplish in any systematic way. This is particularly true at the secondary level where the compartmentalization of subject areas, the pressure to 'cover the content', the urgency of the students to be mainstreamed, and the perceived role of the ESL teacher, work to compound the problem. What teachers, both ESL and content, seek are simple, non-demanding instructional techniques by which they can help their ESL learners.

One way teachers can help ESL learners to cope with academic tasks is to enable them to read content-area textbooks, a skill which plays a central role in student learning of the content of subject disciplines, particularly at the secondary level (Gunderson 1985). There have been 
attempts to improve ESL students' comprehension of texts. Customarily, these efforts have focused on familiarizing students with the necessary vocabulary (Bernhardt 1984). However, it has also been pointed out that "such instruction is unlikely to raise the students' interest in reading the text or to prepare them for the culturally and conceptually novel elements of the text" (Taglieber, Johnson, \& Yarbrough 1989, pp. 455-456).

In recent years, theorists have introduced a cognitive psychological perspective into the study of reading. This theory, known as schema theory, maintains that reading comprehension is an interactive process between the text and the prior background knowledge or schemata of the reader (Carrell 1982). If the reader fails to access or activate the appropriate schemata, it is extremely difficult, if not impossible, for her or him to comprehend the text. Results of schema-related research on second language reading comprehension (Carrell 1984a, 1984b; Carrell, Pharis \& Liberto 1989; Urquhart 1984; Benedetto 1984) have shown that reading comprehension is a function of the interaction of text structure with the reader's formal schemata. Other schema-based studies have indicated that the reader's prior knowledge of the content domain significantly affects the comprehension of text; this is particularly true for culture-specific text content (Steffensen, Joag-dev \& Anderson 1979; Cabello 1984; Haus \& Levine 1985). Schema theory, then, appears to help explain why pre-reading activities which activate learners' prior knowledge improve reading comprehension.

Recognizing the role of prior knowledge in understanding text, researchers have in the past two decades taken considerable interest in studying or developing pre-reading techniques to aid in reading comprehension. Techniques include advanced organizers (Ausubel 1960); purpose-setting questions (Rothkopf 1976; Royer, Bates \& Konold 1984); structured-overview (Barron 1979); text structure (Herber 1970); surveying (Meyer \& Freedle 1979); mapping (Armbruster \& Anderson 1984); concept-mapping (Novak \& Gowin 1984); semantic mapping (Johnson, Pittelman \& Heimlich 1986); and pre-teaching vocabulary (Guthrie \& Tyler 1978; Wittrock, Marks \& Doctorow 1975; Anderson \& Freebody 1981; Hudson 1982), most of which have received varying degrees of support in research literature.

In this paper, we shall discuss another technique, key visuals, which we have found to be successful as a pre-reading strategy. Based on a specific conceptual framework (Mohan 1986), the technique encompasses, or lends itself to the use of, many of the strategies cited above. For the past three years, B. Mohan, H. Hooper and the writers have been working on a large-scale project, the Vancouver School Board Language and Content Project (Early, Mohan \& Hooper 1989) which is aimed at increasing ESL and low English proficiency students' academic achievement by 
facilitating student learning. A concern was to develop a simple procedure, using visuals, which would facilitate the reading of content text and which can be used at any grade level in any content area. We concentrated mainly on helping participating teachers develop and use key visuals a) to prepare students to read content text in a way which acknowledges students' background knowledge, and $b$ ) to enable students to incorporate strategies into their own approach to reading content text.

The rest of this article outlines procedures for developing key visuals and incorporating them in content classrooms, with examples from the Project; and reports briefly the results of an experiment conducted to evaluate this technique. Before we proceed, however, we should explain what key visuals are and why we chose key visuals as a tool to prepare students for reading tasks.

\section{Key Visuals}

Key visuals are graphic representations of text/knowledge structures. Text structures are often referred to as patterns, rhetorical relationships, or organizational structures of discourse. Writers interested in the structure of text agree that there are a number of basic patterns which "appear with regularity in text materials used in content classes" (Herber 1970, p. 105). Meyer (1985) identified five basic patterns: collection, description, comparison, causation and problem/solution, which are "rhetorical relationships that can interrelate the greatest amount of text" (Meyer 1985, p. 269). Mohan (1986) suggests that a typical situation includes a certain group of knowledge structures. They are divided into theoretical or background knowledge which includes classification, principles and evaluation; and specific, practical knowledge which includes description, temporal sequence and choice and decision making. Each knowledge structure has distinct linguistic features which set it apart structurally from others. These knowledge structures are fundamental across the curriculum. Their importance in teaching lies in their "potential for language development and for transfer of learning across content area" (Mohan 1986, p. 74). They are very similar to Meyer's (1985) top level text structures. The only difference is that knowledge structures are defined on semantic relations while text structures are determined by the sequential patterns of discourse.

What distinguishes key visuals from other visuals is that key visuals very deliberately develop both content and formal schemata into a single graphic. They provide the shape of structure of the text/knowledge (formal schemata) and, at the same time, the overview of the content (content schemata).

Knowledge structures are not special to text, and are not uniquely textual, although they are reflected in texts and are components of discourse. 
Since knowledge structures are built from semantic relations, they appear across modes of communication, i.e., they can be expressed in written text, oral discourse, graphic form and electronic database programs. What we term key visuals are thus graphic representations of knowledge structures or, in other words, knowledge structures expressed in graphic form. They show the relations between ideas in a way which lowers the language barrier.

Since classification is the same process regardless of content area or sets of objects, the same general form can be used for classifying living things in Science, food groups in Home Economics and systems of government in Social Studies. Similarly the same principles or causation graphic can be used to show the causes and effects of warfare in Medieval times, the causes and effects of immigration in Canada and the causes and effects of indigestion. Key visuals, therefore, communicate the shape of the knowledge and make visible the knowledge structure they represent, and in this way provide a schema which can be accessed again and again, thus facilitating comprehension.

Fig. 1: The Causes and Effects of the Increase in Trade in China during the Han Dynasty

210 B.C. - 220 A.D.

CAUSES

CAUSES

CAUSES

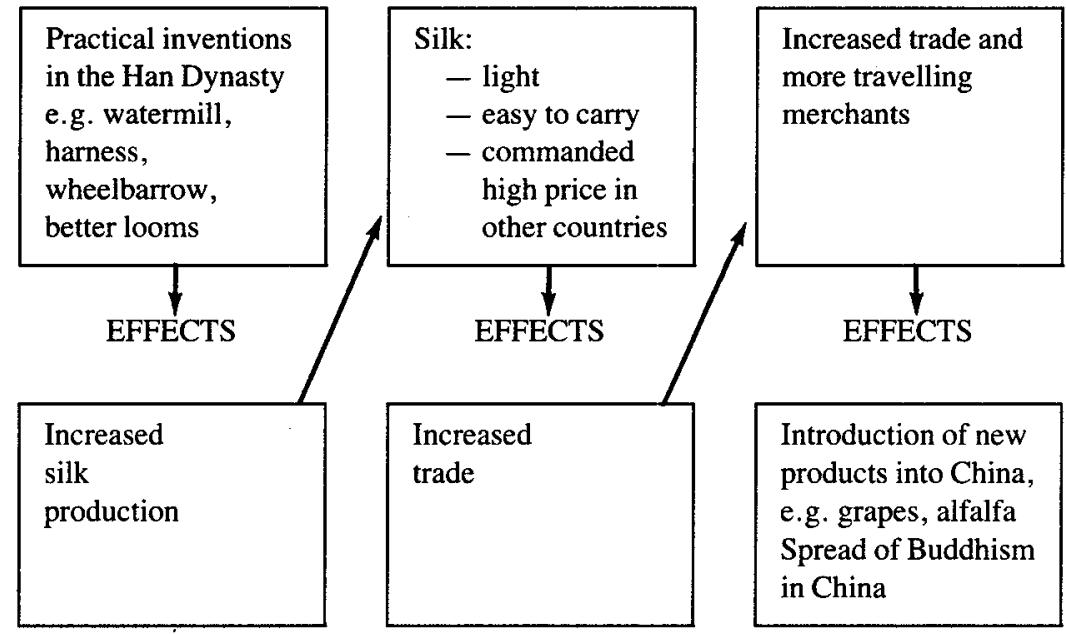

In addition, the key visual also provides a meaningful context for the pre-teaching of vocabulary. It lends itself to the teaching of the linguistic 
features of a particular knowledge structure when the teacher explains the graphic. So, in the graphic showing the causes and effects of the increase in trade in China during the Han Dynasty (see Figure 1), not only can vocabulary items such as "practical inventions," "looms," "wheelbarrow," "harness," "Buddhism," etc., be introduced or reviewed, but the discourse structures particular to principles or causation, e.g., "caused," "led to the growth of. .," "because of. . .," "as a result. .," etc., can also be previewed or reviewed as well. Key visuals also provide a context which can be returned to again, thus helping students to grasp the complex activities involved in the comprehension and production of academic discourse. Finally, key visuals can also be used to critique the comprehensibility of the author's text structure, which is an important reading and writing skill.

\section{Constructing Key Visuals}

In the Vancouver School Board Language and Content Project, we suggested certain forms of key visuals which are typically used to represent each of the knowledge structures (see Figure 2).

Fig. 2: Key Visuals for Knowledge Structures

Classification
\begin{tabular}{|l|l|l|}
\hline $\begin{array}{l}\text { Web, tree, table } \\
\text { graph, database }\end{array}$ & $\begin{array}{l}\text { diagram, graph, } \\
\text { table, cycle }\end{array}$ & $\begin{array}{l}\text { rating chart, } \\
\text { grid, marks book }\end{array}$ \\
\hline $\begin{array}{l}\text { picture, plan, } \\
\text { drawing, slide, } \\
\text { map }\end{array}$ & $\begin{array}{l}\text { flow chart, cycle, } \\
\text { action strip, } \\
\text { time line }\end{array}$ & $\begin{array}{l}\text { decision tree, } \\
\text { flow chart }\end{array}$ \\
\hline Description & Sequence & Choice \\
\hline
\end{tabular}

However, we should point out that these are not the only possible visual forms. Many teachers, when they become more familiar with the process of constructing key visuals, began to create their own forms. Some of these, strictly speaking, did not fit into any of the forms we suggested, but they were, nevertheless, graphic displays which introduced the main concepts of a text and represented the cognitive structure of the interrelationship of those ideas.

Key visuals can be teacher-constructed or student-constructed or constructed jointly by the teacher and students. However, if they are to be produced by students, the teacher will have to instruct students by exposing them to a certain form, modelling the process of construction, and provid- 
ing opportunities for them to practise. Teachers have reported that students initially find it difficult to generate a visual. Some content teachers have also pointed out that it is difficult even for teachers mainly because most expository texts in secondary course books are not pure, but contain elements of several structures (Schallert 1987). The students in particular have difficulty showing the underlying relationship between the ideas in graphic form and labelling the semantic groupings of those ideas in generic terms. They have to struggle through the first few before they become more confident and comfortable with the task. However, most teachers affirm that the process of constructing key visuals has brought about deeper and better understanding of the text by forcing both teachers and students to read it more carefully. In the Language and Content Project we offered the following guidelines for developing key visuals:

\section{Developing a Key Visual}

1. Survey the text to get the gist of the content and the author's conceptual structure in order to identify the sections into which the text might naturally be divided. Each section may be a single paragraph or several paragraphs or even the whole chapter.

2. Read the first section and identify the key ideas which the students should know at the end of the lesson. Then identify the content vocabulary and the discourse structures which will be critical for the students' understanding.

3. Look again at the key ideas, identify and label the knowledge structure inherent in those ideas. You might find it helpful to use the discourse structures (e.g., if-then for cause-effect, first, second, etc., for sequence) to assist you in this process.

4. Look through the section and pick out any aids such as tables, diagrams or charts and evaluate them to determine if they would be suitable for a key visual to depict this section.

5. Work through steps 2-4 for each section of text.

6. When each section of the text has been surveyed and appropriate visuals developed incorporate them into a composite key visual. When incorporating the individual key visuals into a cohesive, comprehensive whole, some adjustments may be necessary.

\section{Using Key Visuals}

Key visuals can be used in different ways to prepare students to read content text. They can be fully developed or partially complete depending on the students' needs and background knowledge. The same key visual can be made use of in a variety of ways. In teaching part of a unit on 'The Crusades' the key visual shown in Figure 3 was developed. 
Figure 3: Crusades

\begin{tabular}{|c|c|c|c|c|c|}
\hline & \multirow{2}{*}{$\begin{array}{c}\text { Early } \\
\text { Crusades }\end{array}$} & \multicolumn{4}{|c|}{ Later Crusades } \\
\hline & & $\begin{array}{c}\text { 2nd } \\
\text { Crusade }\end{array}$ & $\begin{array}{c}\text { 3rd } \\
\text { Crusade }\end{array}$ & $\begin{array}{c}\text { 4th } \\
\text { Crusade }\end{array}$ & $\begin{array}{c}\text { Children's } \\
\text { Crusade }\end{array}$ \\
\hline Dates & & & & & \\
\hline $\begin{array}{l}\text { Causes/ } \\
\text { Purpose }\end{array}$ & & & & & \\
\hline $\begin{array}{l}\text { Results: } \\
\text { Who won }\end{array}$ & & & & & \\
\hline $\begin{array}{l}\text { What was } \\
\text { won }\end{array}$ & & & & & \\
\hline $\begin{array}{l}\text { What was } \\
\text { lost }\end{array}$ & & & & & \\
\hline $\begin{array}{l}\text { Effects: } \\
\text { socio- } \\
\text { economic } \\
\text { benefits }\end{array}$ & & & & & \\
\hline
\end{tabular}

Some possible ways to use this key visual are as follows:

1. Display the key visual on the overhead projector.

2. Activate students' prior knowledge by asking them, with the help of occasional questions, to talk about Early Crusades.

3. Ask students to, or co-operatively with students, put the information they have provided in the appropriate cells of the key visual to complete the column under Early Crusades.

4. To prepare students to read a section of text on Later Crusades, brainstorm information around the topic using the visual as an organizer. It is also possible to guide students to make predictions, to record them in the visual, and to ask them to check their predictions by pointing out the page or paragraph to go to. If their predictions are incomplete, develop their ability to ask purpose-setting questions, and look for answers while they are reading the text. 
5. If students are not ready, build up the visual for them while telling them the story of Later Crusades. Then ask students to retell the story with the help of the visual.

6. While completing the graphic, ask questions to elicit the linguistic features particular to the knowledge structure, in order to introduce, or review, the language necessary for understanding the text.

7. Having gone through some of the above activities, distribute a partially completed graphic for students to fill out while they are reading the text.

The key visual provides a focus for reading. It makes visible the structure of the passage, or if the text contains elements of several structures (Schallert 1987), it highlights the top-level structure of the text, thus, making the text more comprehensible.

Apart from preparing students to read content text, the visual also helps students to think through their reading and to reconstruct their knowledge after reading.

\section{Conclusion}

The techniques and activities we suggested are continually being refined and the materials for supporting or effecting the techniques being evaluated and improved. In the 1989-1990 academic year, the writers and their colleagues conducted a formal evaluation of the technique.

The study, based on a pretest-posttest nonequivalent-control-group design, was replicated in three different situations, Grade 8 Social Studies, Grade 11 Social Studies and Transitional ESL Science, in two secondary schools in Vancouver. The tests were conducted to discover if key visuals facilitated secondary ESL student reading of Social Studies and Science texts and writing of expository prose. The instruments we used were developed from the chapters of the textbooks the students were using at the time of the experiment. The research team prepared key visuals on all the sections to be presented, focusing on two knowledge structures, classification and principles, and the content-area teachers either used or adapted the key visuals we had devised for teaching the experimental group. We organized a number of discussions for each teacher before the pretest, and members of the research team monitored the lessons taught during the period of the experiment, and were at hand for consultation. In all, we administered 24 pretests and 24 posttests. We have initially analyzed 16 of each. Results showed that the experimental group improved in performance in all the eight posttests we analyzed. The control group, however, gained in performance in only two of the posttests; the score of the other six posttests either remained unchanged or regressed.

We have yet to effect finer analysis of the data we have gathered. 
However, as a first step, these results are promising. The positive findings across three quite different situations strongly support the hypothesis that using key visuals to present content-area knowledge can increase secondary ESL students' ability to read content text and write academic discourse, and provide tangible evidence of the facilitative effect of key visuals on reading comprehension. Key visuals, thus, appear to have the potential for saving ESL students from the fate of being "left to struggle with both the rigors of academic material and the difficulty of learning to comprehend text in English" (Gunderson 1985, p. 52).

\section{REFERENCES}

Anderson, R.C., \& Freebody, P. (1981). Vocabulary knowledge. In J.T. Guthrie (Ed.). Comprehension and teaching: Research reviews (pp. 71-117). Newark, New Jersey: International Reading Association.

Armbruster, B.B., \& Anderson, T.H. (1984). Mapping: Representing informative text graphically. In C.D. Holley, \& H.F. Dansereau (Eds.). Spatial learning strategies (pp. 189-209). New York: Academic Press.

Ausubel, D.P. (1960). The use of advance organizers in the learning and retention of meaningful verbal material. Journal of Educational Psychology, 63, 267272.

Barron, R.F. (1979). Research for classroom teachers: Recent development on the use of the structured overview as an advance organizer. In H.L. Herber, \& J.D. Riley, (Eds.). Research in reading in content areas: The fourth report (pp. 29-39). New York: Syracuse University, Reading and Language Arts Centre.

Benedetto, R.A. (1984). A psycholinguistic investigation of the use of top-level organizational strategies in first and second language reading: Five case studies. Ph.D. Dissertation, New York University.

Bernhardt, E.B. (1984). Toward an information processing perspective in foreign language reading. Modern Language Journal, 68, 322-332.

Brinton, D.M., Snow, M.A. \& Wesche, M.B. (1989). Content-based second language instruction. New York: Newbury House.

Cabello, B. (1984). Cultural interference in reading comprehension: An alternative explanation. Bilingual Review II (1), 12-20.

Carrell, P.L. (1982). Cohesion is not coherence. TESOL Quarterly, 16, 478-488.

Carrell, P.L. (1984a). Evidence of a formal schema in second language comprehension. Language Learning 34(2), 87-112.

Carrell, P.L. (1984b). Schema theory and ESL reading: Classroom implications and applications. Modern Language Journal 68(4), 332-343. 
Carrell, P.L., Pharis, B.G., \& Liberto, J.C. (1989). Metacognitive strategy training for ESL reading. TESOL Quarterly 23(4), 647-673.

Chamot, A.U. (1983). Toward a functional ESL curriculum in the elementary school. TESOL Quarterly 17, 459-471.

Chamot, A.U. \& O'Malley, J.M. (1986). A cognitive academic language learning approach: An ESL content-based curriculum. Rosslyn, VA: National Clearinghouse for Bilingual Education.

Early, M., Mohan, B., \& Hooper, H. (1989). The Vancouver School Board Language and Content Project. In J.H. Esling (Ed.). Multicultural Education and Policy: ESL in the 1990s (pp. 107-122). Toronto, Ontario: OISE.

Early, M., Thew, C., \& Wakefield, P. (1986). Integrating language and content instruction K-12: An ESL resource book, Vol. 1. Victoria, B.C.: Ministry of Education, Modern Language Services Branch.

Gunderson, L. (1985). A survey of L2 reading instruction in British Columbia. The Canadian Modern Language Review, 42(1), 44-55.

Guthrie, J.T., \& Tyler, S.J. (1978). Cognition and instruction of poor readers. Journal of Reading Behaviour, 10(1), 57-58.

Haus, G.L., \& Levine, M.G. (1985). The effect of background knowledge on the reading comprehension of second language learners. Foreign Language Annals, 18(5), 391-397.

Herber, H.L. (1970). Teaching reading on content areas. Englewood Cliffs, New Jersey: Prentice-Hall.

Hudson, T. (1982). The effects of induced schemata on the "short circuit" in L2 reading: Non-decoding factors in $\mathrm{L} 2$ reading performance. Language Learning, $32,1-31$.

Johnson, D.D., Pittelman, S.D., \& Heimlich, J.E. (1986). Semantic mapping. The Reading Teacher, 39(8), 778-783.

Meyer, B.J.F. (1985). Prose analysis: Purposes procedures \& problems. In B. Britten, \& J. Black (Eds.). Understanding expository text (pp. 269-285). New Jersey: Erlbaum.

Meyer, B.J.F., \& Freedle, R. (1979). The effects of different discourse topics on recall. Princeton, New Jersey: Educational Testing Service.

Mohan, B.A. (1986). Language and content. Reading, Massachusetts: AddisonWesley.

Novak, J.D., \& Gowin, D.B. (1984). Learning to learn. Cambridge: Cambridge University Press.

Rothkopf, E.Z. (1976). Writing to teach and reading to learn: A perspective in the psychology of written instruction. Psychology of teaching methods (pp. 91129). National Society for the Study of Education, Seventy-fifth Yearbook. 
Royer, J.A., Bates, J.A., \& Konold, C.E. (1984). Learning from text: Methods of affecting reader intent. In J.C. Alderson, \& A.H. Urquart (Eds.). Reading in a foreign language (pp. 65-81). London: Longman.

Schallert, D. (1987). Thought and language, content and structure in language communication. In S. Urbana (Ed.). The dynamics of language learning (pp. 29-39). Illinois: National Conference on Research in English.

Steffensen, M.S., Joag-dev, C., \& Anderson, R.C. (1979). A cross-cultural perspective on reading comprehension. Reading Research Quarterly, 15, 10-29.

Taglieber, L.K., Johnson, L.L., \& Yarbrough, D.B. (1988). Effects of prereading activities on EFL reading by Brazilian college students. TESOL Quarterly, 22(3), 455-472.

Urquhart, A.H. (1984). The effect of rhetorical ordering on readability. In J.C. Alderson, \& A.H. Urquhart (Eds.). Reading in a foreign language (pp. 160 . 175). London: Longman.

Wittrock, N.C., Marks, C., \& Doctorow, M. (1975). Reading as a generative process. Journal of Education Psychology, 67, 484-489.

Wong-Fillmore, L. (1989). Teaching English through content: Instructional reform in programs for language minority students. In J.H. Esling (Ed.). Multicultural education policy: ESL in the 1990s (pp. 125-143). Toronto, Ontario: OISE.

\section{THE AUTHORS}

Margaret Early (Ph.D. UCLA) is Assistant Professor in the department of language education at the University of British Columbia, and co-director, with Bernard Mohan, of a large-scale language and content project in the Vancouver School district. She was previously the provincial coordinator for ESL and multicultural education for the province of British Columbia, and ESL consultant for the Vancouver school board. Her research interests are in the planning and implementing of programmes for school-aged ESL children. She is particularly interested in considering ways to increase ESL students academic achievement.

Gloria M. Tang was educated at the University of Hong Kong, Moray House College of Education, Edinburgh, and The University of British Columbia. She has been an ESL teacher/teacher educator in Hong Kong for over twenty years and is now a lecturer at UBC. She is involved in research in integrating language and content to enhance ESL student learning. 